\title{
Introduktion till temanumret social omsorg $i$ socialt arbete
}

\author{
STINA JOHANSSON
}

\begin{abstract}
Socionomprogrammen har sedan ett kvarts sekel en väl etablerad forskning $i$ ämnet socialt arbete, medan de sociala omsorgsutbildningarna fram tills nyligen saknat en sådan forskningsanknytning. Det innebär inte att det inte forskats om omsorg, men forskningen har varit spridd på olika discipliner och/eller yrkesutbildningar. Den forskning som finns är som regel riktad mot den sociala omsorgens målgrupper, äldre och funktionshindrade. Det är emellertid inte säkert att dess fokus är det sociala arbetets/den sociala omsorgens.
\end{abstract}

I detta nummer presenteras exempel på aktuell forskning inom socialt arbete och social omsorg som kunskapsfält. De inkomna och accepterade artiklarna har, trots att inbjudan var vidare än så, med något undantag kommit att handla om äldreomsorgen. Forskning om den sociala omsorgen får i detta nummer exemplifieras av forskning om svensk äldreomsorg, med utblickar mot Norden och Europa.

Socialt arbete följer en forskningstradition som sätter i centrum sociala problemdefinitioner, undersökningar av orsaken till sociala problem samt analyser av samhällsinterventioner för att påverka eller undvika

Stina Johansson är professor i socialt arbete med inriktning mot social omsorg vid Umeå universitet. dessa förhållanden. Social omsorg inriktas, däremot, på att utveckla redskap och strategier som möjliggör för utsatta grupper att bibehålla eller återupprätta sin funktionsförmåga och skapa förutsättningar för en god livskvalitet.

Traditionen i socialt arbete är att behandla sociala problem, att återföra den avvikande till det normala. Vi kan kalla det behandlingsperspektivet. Traditionen $\mathrm{i}$ social omsorg är att bevara eller återskapa. Fokus ligger på livskvalitet, inte primärt på förändring. Vi kan kalla det omsorgsperspektivet eller serviceperspektivet, beroende på om betoningen ligger på ömsesidigheten och det personliga engagemanget där både givare och mottagare kan påverka, eller på den enskilde mottagarens auto- 
nomi. Men visst finns det väl förändringsmoment också i det sociala omsorgsarbetet, och visst syftar också det sociala arbetet till att bibehålla och återskapa? Det finns skäl att låta tänkandet för såväl det traditionella sociala arbetet som den sociala omsorgens organisering låta sig inspireras av varandras tankegods och grundläggande värderingar.

Gränser mellan verksamheter är ständigt under förhandling. Allt ifrån små till stora ombildningar sker, om man får tro Andrew Abbott, i skuggan av andra förändringar i omvärlden. Alkoholpolitiken ändrar sig efter krav från omvärlden. Alkoholforskningen anpassar sina frågeställningar. Så är det också med samhällets ansvar för de äldre som blivit en viktig grupp på grund av deras allt större andel av befolkningen. Sådant påverkar organiseringen av välfärd. Också samhällets förändring i en mångkulturell riktning påverkar lagstiftning och normsystem. Modern forskning om professioner visar på omgivningens påverkan på yrkesgruppers arbetsinnehåll. Att äldre i samhället blir en allt viktigare grupp för många yrkesgrupper, inte bara socionomer, kan innebära att kampen mellan närliggande yrken om att få arbeta med en alltmer differentierad grupp äldre kan komma att skärpas.

På flera håll i landet har socionomprogrammen och de tidigare sociala omsorgsutbildningarna slagits ihop, vilket lett till en mer eller mindre långt gången integration. På andra håll har sociala omsorgsutbildningarna vidgat sitt utbildningsinnehåll och fått examensrätten som socionomprogram. Under de närmaste åren kommer mycket att hända i och kring dessa två utbildningar då de båda varit föremål för Högskoleverkets och Socialstyrelsens utredning, redovisad i rapporten Social omsorgsutbildning och socionomutbildning (Högskoleverkets rapportserie 2003:29R).

$\mathrm{Nu}$ är ju inte gränserna mellan olika kunskapsområden och/eller verksamheter desamma runt om i världen. Bara i Europa kan man se många skillnader i hur man ser på innehållet i social omsorg. Vad räknas dit och vad räknas inte dit? Att det som i Sverige skulle handla bara om äldreomsorg och omsorg om funktionshindrade är inte självklart i Europas övriga länder. I många länder räknas barnomsorg till social omsorg, medan det i Sverige faller inom utbildningssektorn. Att ta hand om fosterbarn är social omsorg i England, medan det i Sverige räknas som socialt arbete. Eftersom det oftast är kvinnors arbete det handlar om gränsar omsorgen i högre utsträckning till familjearbete och det obetalda arbetet där än vad det sociala arbetet traditionellt sett gör. Omsorg har blivit ett område för den feministiska forskningen, vilket gör den sociala omsorgen forskningsmässigt unik jämfört med forskningen inom exempelvis socialt arbete, omvårdnadsvetenskap eller medicin.

Mer rationellt än vår administrativa indelning vore att tänka i ett "från vaggan till graven«- perspektiv, att ge begreppet social omsorg en mer teoretisk innebörd. Att bevara och stötta den enskildes förmågor och självständighet i vardagen skulle kunna vara centrala mål. Ett omsorgstänkande kunde finnas i olika typer av socialt stöd i livets alla skiften. Peter Moss och Claire Cameron utvecklar i sin artikel med utgångspunkt i erfarenheterna från forskningsprojektet Care Work in Europe: Current Understan- 
dings and Future Directions komplexiteten i begreppet social omsorg/social care.

Vilka föreställningar om äldre grundar sig omsorgen på? Gamla som tacksamma och krav- och orkeslösa, sjuka och hjälpberoende är bilder som är djupt rotade såväl i forskning som i yrkesutövning. Dessa bilder stämmer inte längre. De gamla är friskare än tidigare, även om det kommer signaler om att de allra äldsta inte längre fortsätter denna trend. Det är egentligen bara ett litet antal av pensionärerna som får hjälp från samhället.

Många pensionärer har tid och ork över för annat än att stå i kö för hemtjänst eller sjukvård. Samtidigt ökar kraven på var och en. En arbetskraftsreserv med möjligheter att lönearbeta till 72 års ålder? En resurs för frivilligarbete? De är inte längre enbart mottagare av hjälp, utan förväntas också bidra till samhället. En grupp som är van att fatta egna beslut och som inte låter sig hunsas med. Pensionärer har dessutom blivit en grupp att ta hänsyn till politiskt. De blir resurser. Bengt Eriksson problematiserar äldre i förhållande till den etablerade omsorgsorganisationen, som han menar bygger på industrisamhällets värderingar trots att samhället redan är inne i en annan utvecklingsfas. Samhället är inte lika tryggt, i betydelsen förutsägbart, längre. Till skillnad från industrisamhällets risker som i stor utsträckning var lokala, synliga och möjliga att åtgärda, är nutida risker delvis producerade av vår egen individcentrerade livsstil. Vi själva får ta ansvar för det egna livsprojektet, göra våra egna överväganden och konsekvensbedömningar. Trovärdig kunskap måste finnas för att kompensera individens kunskapsbrist vid beslut om komplexa problem. Tillit till samhällets institutioner och förtroende för dess yrkesutövare är en viktig faktor. Den omsorg som kan bli framtidens är, enligt Erikssons analys, dels inriktad på den fjärde åldern, de allra äldsta, dels professionell och högteknologisk. Flexibilitet och effektivitet, och givetvis också personlig omtanke, är vad som förväntas i ett samhälle där vi i större utsträckning förväntas klara oss själva och fatta egna beslut.

Forskningen kan spela en viktig roll som förändringsagent genom att problematisera villkoren. Att våld mot äldre förekommer, antingen det sker inom familjen eller i den offentliga vården, ingår säkert inte $i$ vår föreställningsvärld. Våld mot äldre har länge varit tabubelagt att tala om. Få forskare har intresserat sig för det. De som gjort det har kommit från discipliner som sociologi eller omvårdnad/geriatrik. Att man i sociala verksamheter inte tagit upp det kan möjligen bero på att äldreomsorg inte tillhört det sociala arbetets huvudspår samt bristen på forskning inom den sociala omsorgen. Ändå är det ett så omfattande problem, både våld i familjen och våld $\mathrm{i}$ vården, något som Håkan Jönson tar upp i sin artikel Övergrepp mot äldre i två perspektiv.

Hur ska man då se på våld mot äldre? Som avvikelse och lagbrott betraktat tillhör våld mot enskilda personer, i familjen eller på gatan, något som socialarbetare länge arbetat med. Men vilket perspektiv ska man anta som forskare? Ska man anamma det perspektiv på våld som utvecklats inom den feministiska forskningen där forskare framför allt i Norden relaterat våldet till kulturella och sociala aspekter av manlig 
dominans/normalitet och kvinnlig underordning, eller ska man fokusera övergrepp mot äldre som problem som ska undersökas och lösas inom ramen för en vårdsituation? Ska man se på våldet ur ett juridiskt perspektiv, med tydliga offer respektive förövare, eller ska man se på våldet som en konsekvens av åldrandet? I båda perspektiven blir våldet problematiskt. Offret respektive förövaren blir otydliga rollfigurer om man ska se våldet som något som ska förstås som en realitet i en omsorgsrelation. Våld mot äldre män blir oproblematiserat i den feministiska forskningen.

Den mesta forskningen inom socialt arbete/social omsorg riktar sig mot verksamheterna, arbetsmetoder, arbetsinnehåll, och har inte alltför sällan ett organisationsteoretiskt anslag. Nog så viktigt är att studera det konkreta arbetet som det fungerar för dem som står mitt uppe i det. Ett viktigt yrke att förstå är biståndsbedömarens. En mäktig grupp då det gäller att översätta lagstiftningens diffusa mål och anpassa insatser till vad som är möjligt inom ramen för kommunernas budget. Flera doktorsavhandlingar har nyligen kommit om denna yrkesgrupp, eller är på väg.

I detta nummer presenterar Katarina Andersson en delstudie på biståndsbedömare i en medelstor stad. Hennes analys rör deras beskrivning av de gemensamma riktlinjer som denna grupp utarbetat på lokal nivå, men skildrar på ett djupare plan biståndsbedömarnas utsatta situation i en begränsad kommunal ekonomi. Deras gemensamma - och lokala - handlingsstrategi byggs upp för att foga sig i en begränsad ekonomi mer än för att förstå och anpassa insatserna till de hjälpsökandes behov. Teo- rier om social omsorg betonar som regel den asymmetriska och ömsesidiga relationen mellan en givande och en mottagande part. I Anderssons material, som ju skildrar den nivå där besluten fattas, kan man skönja en annan struktur. Biståndsbedömaren och de äldres anhöriga bildar, i alla fall som arbetsrutinerna beskrivs, en mer symmetrisk relation där förhandlingen om bistånd kan ske direkt och förbehållslöst. Artikeln lämnar många frågor efter sig. Det är ofta kvinnor som förhandlar om kvinnors rätt till hjälp. Vilken betydelse har det för vilka gemensamma föreställningar, värderingar och arbetsformer som växer fram?

Att avståndet mellan ledning och omsorgsmottagare är stort konstaterar Ulla Melin Emilsson i sin artikel Gruppboende för dementa - en omsorgsform eller ett begrepp $i$ försvinnande? Inspirerad av Mia Vabø introducerar hon begreppen styrningsspråk och vardagsspråk. Styrningsspråket emanerar från administratörernas och planerarnas värld, medan vardagsspråket är det som vårdbiträden och annan frontlinjepersonal använder. I artikeln visar hon vilka skilda språkvärldar de rör sig inom. Trots att gruppboendet i sin ursprungliga form inte existerar länge, om det ens gjort det någon gång, pratar vårdpersonal om det som om det fortfarande existerar i oförändrad form. Tendensen verkar vara densamma också i Frankrike och Portugal, vilket leder till funderingar om ideologiers makt över såväl tanken som upplevelsen.

Avståndet mellan lagstiftningens intentioner och dess tillämpning är något som Ann-Britt Sand är uppfylld av. Hon diskuterar i sin artikel Förändrad tillämpning av offentlig äldreomsorg - ett hot mot målsätt- 
ningen om demokrati och jämställdhet vad nedskärningarna i äldreomsorgen betyder för de anhöriga som tvingas ta ett allt större ansvar för sina sjuka familjemedlemmar. Det blir problem i ett samhälle som lagstiftningsvägen för länge sedan övergivit synsättet att familjen är minsta basen för omsorg, och istället införde individen som minsta enhet när det gäller att formulera rättigheter och skyldigheter. När de flesta kvinnor förvärvsarbetar och socialförsäkringssystemet är anpassat därefter betyder ett ökat ansvar för familjens äldre många ofördelaktiga konsekvenser, t.ex. lägre pension. Dessutom går det emot de äldres egna önskemål. Om vi ska se våra gamla som friska och aktiva får det konsekvenser som kräver mer genomtänkta lösningar som skyddar och inte bestraffar individen.

Flera av artiklarna handlar om ett tydligt "glapp« mellan olika företeelser ute i de studerade verksamheterna. Det kan vara glappet mellan retorik och praktisk verklighet, det kan vara glappet mellan ekonomiska villkor och registrerade hjälpbehov, det kan vara glappet mellan hur socialarbetare tror de gamla har det och hur de gamla verkligen har det. Man kommer osökt att tänka på Thomas Kuhns bok The Structure of Scientific Revolutions från 1962. Kuhns tes är att vetenskapen utvecklas genom en rad icke rationella handlingar där varje förändring betraktas som ett steg mot en djupare förståelse, utan att det nödvändigtvis behöver vara det. "Glappen« eller anomalierna i det som han kallar det rådande paradigmet - konstellationen av gemensamma föreställningar, värderingar, arbetsformer m.m. blir så småningom för många och då tvingas en förändring fram. Efter ett antal försök att pussla ihop kunskapsbilden och dess materialisering i form av arbetsmetoder, yrkesutbildningar och ideologier, tvingas man förr eller senare att ge upp. Om samma resonemang som gäller för vetenskap också kan gälla för andra kunskapsbaserade verksamheter kan man alltså räkna med att den sociala omsorgen - här exemplifierad med äldreomsorgen - kommer att förändras inifrån på grund av anomalier kors och tvärs, nerifrån och upp, uppifrån och ner, samt $\mathrm{i}$ sidled.

Jag tror, som sagt, att forskningen har en viktig funktion att fylla även om den på sikt leder till en professionalisering, en företeelse som kritiserats mycket framför allt i norsk forskning om social omsorg. Enbart erfarenheten som kunskapsbas räcker inte fullt ut i ett system i snabb förändring. Verksamheten har blivit alltför komplex. Det tycker jag detta temanummer ger många exempel på. Däremot bör man hålla ett öga på forskningens avarter, att forskning också innebär makt.

Inspirerad av diskussionen kring kunskapsbaserad socialtjänst har jag frågat ledande personer i den branschen hur de skulle gå till väga för att arbeta mer kunskapsbaserat med de äldre. Tänkandet kring kunskapsbaserad socialtjänst har som det presenterats hittills varit mest kopplat till det som ovan presenterats som behandlingsperspektivet. Kan tänkandet kopplas till omsorg och/eller service? Ett begrepp som förekommer i dessa diskussioner är "process outcome« som innebär att själva bedömningsprocessen operationaliseras i termer av delaktighet i biståndsbeslut, inflytande över vardagens struktur m.m. i stället för på enbart inklusionskriterier och 
resultatvariabler. Detta skulle kunna leda till en alternativ kunskapsuppbyggnad för äldreomsorgens framtida tjänsteinnehåll och struktur, där äldres egna röster skulle kunna bli tydligare.

Lars Evertsson och jag utvecklar i en slutreflektion till detta nummer några tankar om behoven av nya tankespår också inom det sociala arbetets/sociala omsorgens område. Under arbetet med detta temanummer har det än en gång stått klart att de äldre själva, och deras vardag, kommer i bakvattnet av forskning om hemtjänst med fokus på hjälparbetet. Vi pekar på denna lucka och försöker blicka framåt.
I numret presenteras artiklar som endast speglar en bråkdel av den kunskapsutveckling som pågår inom omsorgsområdet. Här finns också en recensionsavdelning som ger en bredare illustration av vad som finns. Inte mindre än tre doktorsdisputationer med relevant innehåll för detta tema genomfördes vid Stockholmsinstitutionen under våren 2004. Två av dem är recenserade i detta nummer.

Ett stort tack till referees som läst omsorgsfullt och generöst föreslagit förbättringar. 